\title{
Case study: How can a portal enhance access to the information needed by a private investor in the stock market?
}

\author{
H.Z. Esterhuizen \\ Postgraduate Diploma in Information Management \\ Rand Afrikaans University
}

\section{Contents}

Introduction

Definition of key concepts

Information needs of an investor in the stock market

The role of a portal in enhancing access to information

The portal of Tradek.com

Conclusion

References

\section{Introduction}

Information regarding share prices and the daily movements of share prices, the financial results and other information about companies on the stock exchange are freely available on the Internet. On-line trading facilities make it possible for a private investor to have direct and immediate access to a stockbroker, and buy and sell orders can be sent online for immediate execution.

This article looks at a portal as a possible solution to the time-consuming problem of gathering and interpreting information. Special reference are made to the Web site of Tradek.com as a typical stock market portal.

How can a portal enhance access to the information needed by a private investor in the stock market? When this problem is addressed, several sub problems should be considered.

- What is a portal?

- What is a private investor?

- What are the information needs of an investor in the stock market?

- What role does a portal play in enhancing access to information?

- How does Tradek.com perform as a typical stock market portal?

- What strategies are used to enhance access to information? 


\section{Definition of key concepts}

\section{A portal}

Green (2000) define portals as those Web sites that are jockeying for pole position as starting points for the Internet user's experience.

According to Rowley (2000), an Internet portal is a Web site that provides an entry point to the Internet, and offer value-added services such as directories, searching, information news, and links to related sites.

Detlor (2000) describe corporate portals as single point Web browser interfaces used within organizations to promote the gathering, sharing and dissemination of information throughout the enterprise.

Although the definitions differ, several aspects are similar. After considering these definitions, the following working definition is considered appropriate:

A portal is a Web site that acts as an Internet starting page that offers users access to information, value-added services and links to other providers of information and services.

\section{Private investor}

A private investor is a person who invests his/her own money on the stock market and manages this portfolio of shares.

\section{Information needs of an investor in the stock market}

An investor in the stock market is absolutely dependent on information for achieving success. A private investor has wide-ranging information needs such as information about:

- trends in the global economy and how they would influence the local economy;

- local political and economical trends and their influence on local share prices.;

- which industries seem to be the most profitable and which would be profitable in future;

- trends in share prices;

- day-to-day information and news on current global and local political and economic affairs;

- economic indicators like interest rates, the oil price, the gold price and the various share indexes; and

- in depth information on South African companies and their share prices.

To acquire all the necessary information can be a serious problem for a private investor due to the time factor, as this information must usually be gathered from several different Web sources. The solution for an investor would be a Web site that provides all this information or links to this information.

An Internet portal could be a solution to this problem. 
Portals offer a range of value-added services to encourage users to visit their portal. Typically, information and access to other Web sites that is available via the portal is organized so that users can find information that might be of interest to them. Many portals offer communication facilities, such as e-mail, message boards, chat lines, forums and news groups. The purpose of this is to encourage frequent repeat visits and the creation of a community that is associated with the portal (Rowley, 2000). Portals are also of great value to the electronic commerce, marketing and advertising industry due to the potential power of the portals in directing consumers towards products and services.

The main purpose of a portal should be to manage information. It has to be designed to incorporate the electronic storage of customized, maintained, useful information, categorized for easy access and usage (Queck, 1999).

Important aspects are:

\section{Customization}

Part of the real value of a portal would be the ability to recognize the individual user's information needs and 'fetch' or 'push' new information to that user on an individual basis.

Maintenance

The information has to be selected, structured, developed, organized and reorganized on an ongoing basis so that it is always relevant, pertinent and up?to?date.

\section{Categorization}

The portal must be intelligently designed so that the user can get the relevant information quickly and intuitively

Accessibility and usability.

A portal must be highly user friendly and easy to access and use.

A search facility in a portal is a valuable tool to a user. A new trend in portals is to provide links to popular search engines. Some portals also provide an internal search facility through which the contents of the site can be searched.

\section{The portal of Tradek.com (http://www.tradek.com)}

Tradek.com is the portal of a stockbroker. Tradek.com is focused on providing facilities for on-line share trading. In addition to this, it provides comprehensive information and services regarding private investment and related matters.

\section{Information provided by Tradek.com}

Tradek.com provides the following:

- A daily share market update

- Daily company and business news

- News on international markets

- Information regarding the latest trading on the Johannesburg Stock Exchange (JSE). This includes information about JSE indices and a summary of shares with the biggest price movements

- Information and comparisons on warrants

- Results on research into companies 
- Analysis of companies and individual shares

- Information about new listings and suspensions on the stock exchange are supplied daily

- Customer surveys

- Investment opportunities in South African unit trusts

- Information on new technology like WAP (Wireless Application Protocol).

Tradek also maintains several investment funds with different risk profiles. Full information and advice about these funds is provided to investors. The names and focus of the funds are:

- Top-gear: warrant opportunities

- Hypertwister: geared equity and bond warrants

- Terra-firma: resources warrants

- Third Millennium growth: growth stocks

- White Knuckle: high growth stocks

- Short-circuit: technology stocks

- NetNet: Internet companies

- Wide-eyed: blue-chip shares

This information is provided free of charge. Some services are only accessible to account holders, although there is no charge for opening an account.

\section{Services accessible from the portal}

The most important service that is provided by Tradek.com is the opportunity to do on-line share trading on the JSE.

Other services that are provided are:

- Access to live JSE prices

- A news service which immediately notifies the investor via e-mail when shares or warrants are bought or sold in the fund(s) that is (are) selected by the investor

- Investment advice

- Managed portfolios

- Offshore products

- Tax planning

- Life insurance

- Estate planning

- Planning and setting up of trusts

- Opening of an account through the completion of an online application Online transferring of money to and from a stock broking account

- Online managing of a portfolio of shares

- An archive of company information

- Trading in shares in the USA

- A share chat service

- Several e-mail newsletters.

\section{Strategy used by Tradek.com to enhance access to information}

Tradek.com uses with other financial sites to broaden the range of services and products provided to users.

Maudestreet (http://www.maudestreet.com) is a private client research tool from Vantage Investment Solutions, an independent equities research house. The purpose of Maudestreet is 
to:

- provide a quality research service to enhance private client stock broking businesses;

- combine current market information with fundamental, economic and technical research to deliver a quality research product;

- provide coverage of small to mid-cap stocks - those stocks in which private investors are interested, but on which there is little quality research;

- provide in-depth research on selected new listings; and

- provide definite buy and sell decisions.

Tradek.com also provide links to 18 other financial and investment Web services. Some of them are as follows:

- Moneymax (http://www.moneymax.zo.za). A financial Website with links to online stockbrokers. Their ad claims, "Where the smart money's going."

- Moneyweb (http://www.moneyweb. co.za). Alec Hogg's on-line investment Web site.

- Summet (http://www.summet.co.za). A South African business channel, exclusive to DSTV.

- Business Day (http://www.bday.co.za). South Africa’s premier daily business newspaper.

- I-africa (http://www.iafrica.co.za). The latest local and international business news and features.

- Netassets (http://www.netassets.co.za). Personal money management - an I-Net Bridge Web site.

- Sharenet (http://www.sharenet.co.za). A Web site on investments.

All these links provide additional information and services to users.

\section{Conclusion}

A portal is a valuable tool for users to obtain access to information and services. A portal's great advantage is that it adds value to information and saves time and effort.

The portal of Tradek.com is a good example of a typical stock market portal that provides and enhances access to information and services to private investors. This portal provides a wide range of information, in fact, all the information needed by a private investment enterprise. Where the information is not provided, links to the information are provided.

Associates and partnership arrangements are used as strategies to enhance access to information. The provision of links to Web sites that can provide additional information and services to users are also used as a strategy to enhance access to information and services to users.

The portal is easy and quick to use and of great value to a private investor.

\section{Reference}

Detlor, B. The corporate portal as information infrastructure: towards a framework for portal design. International journal of information management, 20(2): 91?101. HTML 
Green, D. 2000. The evolution of Web searching. Online information review, 2(2): 124?137. HTML

Queck, C. 1999. Portal power - taming the corporate intranet. Knowledge management 1(4): 32?38. HTML

Rowley, J. 2000. Portal power. Managing information, 7(1): 62?64. HTML

Tradek.com. 2000. [Online]. Available WWW: http://www.tradek.com

\section{Disclaimer}

Articles published in SAJIM are the opinions of the authors and do not necessarily reflect the opinion of the Editor, Board, Publisher, Webmaster or the Rand Afrikaans University. The user hereby waives any claim he/she/they may have or acquire against the publisher, its suppliers, licensees and sub licensees and indemnifies all said persons from any claims, lawsuits, proceedings, costs, special, incidental, consequential or indirect damages, including damages for loss of profits, loss of business or downtime arising out of or relating to the user's use of the Website. 
ISSN 1560-683

Published by InterWord Communications for the Centre for Research in Web-based Applications, Rand Afrikaans University 